\title{
Provitamin A and Vitamin C Contents of Several Varieties of Mango (Mangifera Indica L.) Grown in Puerto Rico
}

\author{
L. M. Iguina de George, A. L. Collazo de Rivera, \\ J.R. Benero, and W. Pennock 1
}

\section{INTRODUCTION}

Mango (Mangifera indica, $\mathrm{L}_{\text {. }}$ ) is a tropical fruit of high nutritive value as a good source of vitamins $A$ and $C(1,2,3)^{2}$. In Puerto Rico, this fruit grows and shows great adaptability to our warm climate (4). The most common varieties grown are the Mayagüezano and Pasote (5).

The Agricultural Experiment Station of the University of Puerto Rico has introduced a large number of mango varieties suitable for the fresh market and for processing. As part of these studies, the composition of the varieties grown on the experimental farm at the Fortuna Substation on the Southern Coast of Puerto Rico was determined. This paper presents the data obtained from the analyses of 30 varieties.

\section{REVIEW OF LITERATURE}

The vitamin $A$ and vitamin $C$ contents of the mango vary with the origin of the fruit. Indian varieties are reported to contain 12.19 to $42.39 \mathrm{mg}$. of vitamin A and 13.2 to $80.3 \mathrm{mg}$. of vitamin C per $100 \mathrm{~g}$. of pulp (3). For the Bombay varieties, contents of $6.0 \mathrm{mg}$. of $\beta$-carotene and $10.5 \mathrm{mg}$. of ascorbic acid per $100 \mathrm{~g}$. of pulp are claimed (3). Ascorbic acid values for Florida mangos are reported to range from 5.4 to $19.7 \mathrm{mg}$. per $100 \mathrm{~g}$. (6). Twentysix West Indian varieties varied in their vitamin C content from 9.3 to $130.81 \mathrm{mg}$. per $100 \mathrm{~g}$. of pulp (8).

\section{MATERIALS AND METHODS}

Samples of 30 varieties of mango were picked at random at a full-ripe stage, weighed, hand-peeled, and the proportions of peel, pulp, and seed determined. For analyses, the pulp was homogenized in a blender for 5 minutes. Moisture, total solids, insoluble solids, refractometric solids as ${ }^{\circ}$ Brix, total and reducing sugars, vitamin $\mathrm{C}, \beta$-carotene, $\mathrm{pH}$, and total titratable acidity as citric acid were determined in the homogenate. Moisture and

1 Research Assistants, and Associate Chemist and Administrative Assistant, respectively, Food Technology Laboratory, and Horticulturist, Department of Plant Breeding, Agricultural Experiment Station, Mayagüez Campus, University of Puerto Rico, Río Piedras, P.R.

2 Italic numbers in parentheses refer to Literature Cited, pp. 104-5. 
total solids were determined by the vacuum-oven method $(\boldsymbol{\gamma})$, and soluble solids were measured as ${ }^{\circ}$ Brix with an Abbe-type refractometer. Total and reducing sugars determinations were performed by the Lane and Eynon method (8). Column chromatography was used for the $\beta$-carotene determinations (9). Ascorbic acid was determined by Ballantine's method

TABLE 1.-Peel, pulp, and seed conlent of several varieties of mango

\begin{tabular}{|c|c|c|c|c|c|}
\hline Variety & Fruits & $\begin{array}{c}\text { Average weight } \\
\text { of fruits }\end{array}$ & Peel & Pulp & Seed \\
\hline & Number & Grams & Percent & Percent & Percent \\
\hline Edward & 18 & 444.53 & 12.73 & 73.53 & 13.71 \\
\hline Keitt & 19 & 494.42 & 12.05 & 69.88 & 18.28 \\
\hline Springfels & 7 & 653.18 & 10.87 & 68.48 & 20.65 \\
\hline Parvin & - & - & 8.75 & 66.25 & 25.00 \\
\hline Palmer & 10 & 453.60 & 10.41 & 65.63 & 25.08 \\
\hline Davis Haden & 19 & 467.28 & 10.00 & 65.00 & 22.50 \\
\hline Zill & 30 & 226.80 & 13.33 & 65.00 & 20.00 \\
\hline Florigon & 16 & 276.70 & 15.38 & 64.10 & 20.51 \\
\hline Kent & 17 & 535.25 & 10.00 & 62.50 & 28.00 \\
\hline Early Gold & 127 & 272.16 & 18.75 & 61.58 & 18.64 \\
\hline Eldon & 10 & 267.62 & 12.74 & 60.78 & 26.47 \\
\hline Carrie & 18 & 281.23 & 15.89 & 60.74 & 23.30 \\
\hline Succidoro & 27 & 325.60 & 16.25 & 60.00 & 22.50 \\
\hline Ruby & 39 & 181.44 & 11.29 & 59.68 & 29.03 \\
\hline Irwin & 33 & 263.09 & 18.44 & 57.89 & 23.68 \\
\hline Julie & 10 & 263.09 & 15.88 & 57.14 & 25.97 \\
\hline Stringless Peach & 21 & 199.58 & 13.51 & 56.76 & 29.73 \\
\hline Bombay Yellow & 29 & 127.01 & 12.50 & 56.25 & 31.25 \\
\hline Haden & 35 & 290.30 & 16.85 & 56.18 & 25.84 \\
\hline Santaella & 26 & 181.44 & 15.07 & 56.16 & 28.77 \\
\hline Adams & 55 & 131.54 & 17.12 & 54.79 & 28.82 \\
\hline Paheri & 30 & 240.41 & 17.46 & 53.97 & 25.40 \\
\hline Jacquelin & 19 & 376.49 & 14.29 & 53.97 & 23.81 \\
\hline Lippens & 35 & 244.94 & 17.11 & 53.95 & 26.32 \\
\hline Pillsbury & 27 & 195.05 & 17.39 & 52.17 & 30.44 \\
\hline Lathrop & 103 & 140.61 & 16.41 & 50.78 & 33.59 \\
\hline Francisque & 23 & 335.66 & 19.12 & 50.50 & 30.88 \\
\hline Corne & 42 & 149.69 & 23.64 & 32.73 & 40.00 \\
\hline
\end{tabular}

(10), and $\mathrm{pH}$ was measured by the A.O.A.C. glass-electrode method (7). Total titratable acidity as citric acid was determined by a potentiometric titration with $0.1 \mathrm{~N} \mathrm{NaOH}$ standard solution (7).

\section{RESULTS AND DISCUSSION}

The peel, pulp, and seed contents for the 30 varieties studied are given in table 1. The Edward, Keitt, and Springfels have the highest pulp content, 
averaging $73.53,69.88$, and 68.48 percent, respectively. It should be noticed that even though the Springfels produces the largest fruit, with an average weight of $653.13 \mathrm{~g}$., its yield of pulp is only 68.48 percent, which is much lower than for the Edward, the average of which is 73.53 percent. From the standpoint of yield of pulp, these three varieties would be the choice for processing. However, since the overall processing characteristics of these varieties were not studied, further work must be conducted prior to any final selection of fruits for processing.

Values for the chemical analyses performed are given in tables 2, 3, and 4. The varieties have been arranged in three groups according to the $\beta$ carotene content. In table 2 are listed the varieties providing the minimum

TABLE 2.-Chemical composition of different varieties of mango (Mangifera indica,

L.) with $\beta$-carotene ranging from 5,000 to 8,000 I.U./100 g. of pulp ${ }^{1}$

\begin{tabular}{|c|c|c|c|c|c|c|c|c|c|c|c|}
\hline$V_{t}$ & $\begin{array}{c}\beta- \\
\text { carotene }\end{array}$ & $\underset{\mathrm{C}}{\text { Vitamid }}$ & "Brix & pH & $\begin{array}{l}\text { Total } \\
\text { acidity" }\end{array}$ & $\begin{array}{l}\text { Reduc- } \\
\text { ing } \\
\text { sugars }\end{array}$ & $\begin{array}{l}\text { Total } \\
\text { sugars }\end{array}$ & $\begin{array}{l}\text { Mois- } \\
\text { ture }\end{array}$ & $\begin{array}{l}\text { Total } \\
\text { solids }\end{array}$ & $\begin{array}{l}\text { Insol- } \\
\text { uble } \\
\text { solids }\end{array}$ & $\begin{array}{l}\text { Pulp } \\
\text { nter }\end{array}$ \\
\hline & I.U./100 & $\begin{array}{l}M \mathrm{~g} . / 10 \\
\mathrm{~g} .\end{array}$ & & & acent & Percent & Percent & ercent & ercent & $\begin{array}{l}\text { Per- } \\
\text { cent }\end{array}$ & Percent \\
\hline & 7,900 & 45.69 & 18.4 & 4.10 & 0.44 & 3 & 14.52 & 81 & 18.25 & 0.35 & 60 \\
\hline & & 20. & 19.8 & 4.38 & .2 & & & & 2.07 & 2.27 & \\
\hline & & 4.64 & 18.0 & 4.58 & .2 & 4 & 16.15 & & 19.70 & 1.70 & 53. \\
\hline & & 8.78 & 18. & 4.25 & .3 & 3.7 & 15 & 81 & 18.77 & .67 & 54.79 \\
\hline & & 9.99 & 19.5 & 4.01 & .3 & 4 & & & 19.92 & .42 & 65.00 \\
\hline & 5 , & 38.12 & 19.5 & 4.35 & .32 & & 16 & & 19.76 & .26 & 73.53 \\
\hline Sensation & 5,067 & 24.89 & 18.2 & 4.34 & .16 & 3.95 & 14.80 & 81.01 & 18.99 & .72 & - \\
\hline
\end{tabular}

Unit.

2 Expressed as percent citric acid.

daily requirement (MDR) of 5,000 I. U. of vitamin A (11) per $100 \mathrm{~g}$. of pulp; in table 3 those containing from 2,500 to 4,000 I. U. per $100 \mathrm{~g}$. of pulp; and in table 4, those with the lowest $\beta$-carotene content, ranging from 400 to 2,500 I. U. per $100 \mathrm{~g}$. The Carrie had the highest $\beta$-carotene content with 7,900 I. U. per 100 g., while the Stringless Peach had the lowest with 417 I. U. per 100 g. of pulp.

The ascorbic acid content ranged from 3.43 to $62.96 \mathrm{mg}$. per $100 \mathrm{~g}$. of pulp, with the Julie variety showing the highest content and the Keitt variety the lowest. The minimum daily requirement of $75 \mathrm{mg}$. of vitamin C (11) would be surpassed by $200 \mathrm{~g}$. of pulp from the Julie and the Francisque varieties.

The soluble-solids content for all varieties ranged from 14.6 to $23.1^{\circ}$ Brix, the Julie variety having the highest and the Bombay Yellow the lowest (table 3). The acidity varied from a pH of 4.53 in the Succidoro to a $\mathrm{pH}$ of 3.25 in Pillsbury. The varieties having the highest and lowest contents of 
TABLE 3.-Chemical composition of different varieties of mango (Mangifera indica,

L.) with $\beta$-carolene ranging from 2,500 to 4,000 I.U./100 g. of pulp ${ }^{2}$

\begin{tabular}{|c|c|c|c|c|c|c|c|c|c|c|c|}
\hline Variety & $\begin{array}{c}\beta- \\
\text { car- } \\
\text { otene }\end{array}$ & $\begin{array}{c}\text { Vita- } \\
\min \\
C\end{array}$ & ${ }^{\circ}$ Brix & pH & $\begin{array}{l}\text { Total } \\
\text { acid- } \\
\text { ity? }\end{array}$ & $\begin{array}{c}\text { Re- } \\
\text { ducing } \\
\text { sugars }\end{array}$ & $\begin{array}{c}\text { Total } \\
\text { sugars }\end{array}$ & \begin{tabular}{|c|} 
Mois- \\
ture
\end{tabular} & $\begin{array}{l}\text { Total } \\
\text { solids }\end{array}$ & $\begin{array}{l}\text { Insol- } \\
\text { uble } \\
\text { solids }\end{array}$ & $\begin{array}{c}\text { Pulp } \\
\text { con- } \\
\text { tent }\end{array}$ \\
\hline & $\begin{array}{ll}1 . U . / \\
100 \mathrm{~g} .\end{array}$ & \begin{tabular}{|l|}
$M g . /$ \\
$100 \mathrm{~g}$
\end{tabular} & & & $\begin{array}{l}P_{e r-} \\
\text { cent }\end{array}$ & $\begin{array}{l}\text { Per- } \\
\text { cent }\end{array}$ & $\begin{array}{l}\text { Per- } \\
\text { cent }\end{array}$ & 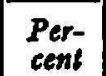 & $\begin{array}{l}\text { Per- } \\
\text { cent }\end{array}$ & $\begin{array}{l}\text { Per- } \\
\text { cent }\end{array}$ & $\begin{array}{l}P_{\text {er- }} \\
\text { cent }\end{array}$ \\
\hline Pillsbury & 4,250 & 11.87 & 16.9 & 3.25 & 0.46 & 3.43 & 14.04 & 82.33 & 17.67 & 0.77 & 52.17 \\
\hline Bombay Yellow & 4,217 & 11.31 & 14.6 & 3.98 & .40 & 4.65 & 11.95 & - & 一 & - & 56.25 \\
\hline Toledo & $\mid 4,133$ & 20.92 & 20.9 & 4.30 & .42 & 7.82 & 18.15 & 78.52 & 21.48 & .58 & - \\
\hline Santaella & 3,983 & 15.77 & 18.4 & 3.80 & .55 & 6.86 & 15.94 & 78.18 & 21.82 & 3.42 & 56.16 \\
\hline Early Gold & 600 & 26.42 & 16.3 & 3.87 & .40 & 3.80 & 14.48 & 82.19 & 17.81 & 1.51 & 61.58 \\
\hline Eldon & 533 & 16.27 & 18.4 & 4.40 & .21 & 9.56 & 16.03 & 81.10 & 18.90 & .50 & 60.78 \\
\hline Julie & 3,250 & 62.96 & 23.1 & 4.34 & .25 & 3.42 & 18.11 & 62.53 & 37.47 & 14.37 & 57.14 \\
\hline Irwin & $|3,150|$ & 37.14 & 15.3 & 4.03 & .28 & 6.37 & $|13.76|$ & 83.11 & 16.89 & 1.59 & 57.89 \\
\hline Francisque & 2,933 & 52.14 & 16.5 & 4.33 & .17 & 4.14 & 14.21 & 83.04 & 16.96 & .46 & 50.50 \\
\hline Succidoro & 2,917 & 37.95 & 16.9 & 4.56 & .22 & 6.52 & 14.30 & 82.19 & 17.81 & .91 & 60.00 \\
\hline Jacq & $2,883]$ & 5.76 & 16.2 & 4.45 & .24 & 2.52 & 13.29 & 81.13 & 18.87 & 2.67 & 53.97 \\
\hline & 833 & 9.25 & 16.3 & 3.90 & .58 & 4.30 & 14.13 & 80.05 & 19.95 & 3.65 & 59.68 \\
\hline Lipr & 2,817 & 17.68 & 16.4 & 4.40 & .30 & 5.05 & 14.78 & 81.46 & 18.54 & 2.14 & 53.95 \\
\hline Lathrop & 2,667 & 25.50 & 21.2 & 3.85 & .60 & 4.45 & 18.75 & 75.41 & 24.59 & 3.39 & 50.78 \\
\hline
\end{tabular}

1 Each figure represents the computed mean of 2 replicates.

2 Expressed as percentage citric acid.

TABLE 4.-Chemical composition of different varieties of mango (Mangifera indica, L.) with B-carotene ranging from 400-8,500 I.U./100 g. of pulp ${ }^{1}$

\begin{tabular}{|c|c|c|c|c|c|c|c|c|c|c|c|}
\hline Variety & $\begin{array}{c}\beta- \\
\text { car- } \\
\text { otene }\end{array}$ & $\underset{\text { Vita- }}{\min }$ & 'Brix & pH & $\begin{array}{l}\text { Total } \\
\text { acid- } \\
\text { ity2 }\end{array}$ & $\begin{array}{c}\text { Re- } \\
\text { ducing } \\
\text { sugars }\end{array}$ & $\begin{array}{c}\text { Total } \\
\text { sugars }\end{array}$ & \begin{tabular}{|c|} 
Mois- \\
ture
\end{tabular} & $\begin{array}{l}\text { Total } \\
\text { solids }\end{array}$ & $\begin{array}{c}\text { Insol- } \\
\text { uble } \\
\text { solids }\end{array}$ & $\begin{array}{l}\text { Pulp } \\
\text { con- } \\
\text { tent }\end{array}$ \\
\hline & \begin{tabular}{ll|}
$1 . U$ & $\mathrm{U} . /$ \\
$100 \mathrm{~g} \cdot \mid$
\end{tabular} & $\begin{array}{c}M g 8 . / \\
100 \mathrm{~g} .\end{array}$ & & & $\begin{array}{l}\text { Per- } \\
\text { cent }\end{array}$ & $\begin{array}{l}\text { Per- } \\
\text { cent }\end{array}$ & $\begin{array}{l}\text { Per- } \\
\text { cent }\end{array}$ & $\begin{array}{l}\text { Per- } \\
\text { cent }\end{array}$ & $\begin{array}{l}\text { Per- } \\
\text { cenl }\end{array}$ & $\begin{array}{l}\text { Per } \\
\text { cent }\end{array}$ & $\begin{array}{l}\text { Per- } \\
\text { cent }\end{array}$ \\
\hline Corne & 2,467 & 45.17 & 20.8 & 4.15 & 0.46 & 8.96 & 16.55 & 75.16 & 24.84 & 4.04 & 32.73 \\
\hline Had & $|2,367|$ & 14.96 & 14.8 & 4.10 & .37 & 3.72 & 12.75 & 83.18 & 16.82 & 2.02 & 56.18 \\
\hline Springfels & 267 & 22.59 & 16.2 & 4.16 & .37 & 3.13 & 13.20 & 一 & - & - & 68.48 \\
\hline Kent & 1,950 & 26.34 & 16.9 & 3.35 & .57 & 4.66 & 14.18 & 79.36 & 20.64 & 3.74 & 62.50 \\
\hline Davis Haden & 1,900 & 4.01 & 19.0 & 4.25 & .22 & 2.78 & 15.25 & - & - & - & 65.00 \\
\hline Florigon & 1,750 & 23.50 & 17.8 & 3.86 & .29 & 4.92 & 14.66 & 81.75 & 18.25 & .45 & 64.10 \\
\hline Keitt & $|1,300|$ & 3.43 & 15.5 & 3.55 & .50 & 4.77 & 12.98 & 81.01 & $18.99 \mid$ & 3.49 & 69.88 \\
\hline Stringless & 417 & 22.81 & 16.6 & 4.38 & .18 & 3.47 & 14.35 & - & - & - & 56.76 \\
\hline Parvin & - & 6.92 & 15.5 & 4.15 & .27 & 4.97 & 10 & 82.40 & $|17.60|$ & 2.10 & 66.25 \\
\hline
\end{tabular}

1 Each figure represents the computed mean of 2 replicates. I.U. = International Unit.

2 Expressed as percent citric acid.

total acidity were the Lathrop and the Sensation with 0.60 and 0.16 percent, respectively. The Lathrop had the highest total sugar content, with 18.75 percent, and the Bombay Yellow the lowest with 11.95 percent.

Six samples of the 30 varieties analyzed in the first test were studied 
again a year later. Although some differences were found in the composition when compared with previous values, these variations were probably due to differences in the degree of ripeness of the fruit when harvested.

\section{SUMMARY}

The chemical composition of 30 mango varieties from the Fortuna Substation in the Southern Region of Puerto Rico was studied. The proportion of peel, pulp, and seed, as well as the moisture content, total and soluble solids, ascorbic acid, total and reducing sugars, $\mathrm{pH}$, total titrable acidity, and $\beta$-carotene were determined for each variety.

Of these varieties, the Edward gave the highest pulp yield; and the Julie and the Francisque had the highest vitamin $C$ values, providing the MDR with 200 g. of pulp. The Carrie, Palmer, Paheri, Adams, Zill, Edward, and Sensation surpassed the MDR of 5,000 I.U. for vitamin A, with the Carrie showing the highest with 7,900 I. U. per $100 \mathrm{~g}$. of pulp.

Six of these varieties were again analyzed the following year. The resulting differences between the same varieties in the 2 years that they were analyzed could be attributed to an error in the visual evaluation of the degree of ripeness of the fruit at harvesttime.

\section{RESUMEN}

Se estudiaron 30 variedades de mangó cosechadas en la Subestación de Fortuna en la Región Sur de Puerto Rico, para determinar la proporción de semilla, cáscara y pulpa, y analizar el contenido de humedad, los sólidos solubles y totales, la vitamina $\mathrm{C}$, las azúcares totales y reductoras, el $\mathrm{pH}$, la acidez total y el $\beta$-caroteno.

De las variedades estudiadas la Edward dio el mayor rendimiento de pulpa; la Julie y la Francisque revelaron poseer el mayor contenido de vitamina C, proveyendo el requisito mínimo diario (MDR) con $200 \mathrm{~g}$. de pulpa; y la Carrie, Palmer Paheri, Adams, Zill, Edward, y Sensation sobrepasaron el requisito mínimo de 5,000 U. I. de vitamina A por cada $100 \mathrm{~g}$. de pulpa, siendo la Carrie la de mayor contenido con 7,900 U. I. por cada $100 \mathrm{~g}$.

Seis de estas variedades fueron analizadas nuevamente el siguiente año. Las diferencias que se encontraron entre los resultados de los dos análisis de las muestras de la misma variedad, podrían atribuirse a un error en la evaluación visual del grado de madurez de la fruta al cosecharse.

\section{LITERATURE CITED}

1. Munsell, H. E., Ascorbic acid content of the mango in relation to variety, Food Res. 11: 95-8, 1946.

2. - The vitamin A, vitamin B (thiamine), ascorbic acid, and riboflavin contents of common foods, Milban $K$ Mem. Food Quart. 21 : 102-8, 1933. 
3. Singh, L. B., The Mango, Interscience Publishers, Inc., New York, N.Y., 1960.

4. Pennock, W., La siembra comercial de mangos en Puerto Rico, Rev. de Agr. de P.R. 47 (2): 75-89, 1960 .

5. Axtmayer, J. H., and Cook, D. H., Manual de Bromatología, Publicación No. 186, Oficina Sanitaria Panamericana, Washington, D.C., 1942.

6. Perry, E. O., and Silva, S. S., Report on the vitamin content of the mango, Agr. and Livestock India s: 74-6, 1933.

7. Official Methods of Analyses of the Association of Official Agricultural Chemists, 10th ed., Washington, D.C., 1965.

8. Jacobs, M. B., The Chemical Analyses of Food and Food Products, 3d ed., D. Van Nostrand Co., Inc., Princeton, N. J., 1958.

9. Methods of Vitamin Assay, 2nd ed., Interscience Publishers Inc., New York, N.Y., 1951.

10. Ballantine, $R$., Determination of ascorbic acid in citrous fruit juices, Ind. and Eng. Chem. Anal. Ed. 13 (2): 89, 1941.

11. Facts About Foods, H. J. Heinz Co., Pittsburgh, Pa., 1960. 